A N N A L E S

UNIVERSITATIS MARIAE CURIE-SKŁODOWSKA

LUBLIN - POLONIA

VOL. LXVI, 1

SECTIO G

2019

Uniwersytet Marii Curie-Skłodowskiej w Lublinie

MAŁGORZATA STEFANIUK

malgorzata.stefaniuk@poczta.umcs.lublin.pl

ORCID: 0000-0002-5029-2254

\title{
Ocena elit politycznych w wystąpieniach w Sejmie Rzeczypospolitej Polskiej VIII kadencji
}

The Assessment of Political Elites in the Speeches of the $8^{\text {th }}$ Term Sejm

of the Republic of Poland

\section{WPROWADZENIE}

Problematyka podjęta w niniejszym opracowaniu dotyczy sposobu, w jaki są postrzegane elity polityczne w niższej izbie polskiego parlamentu, przy czym materiał empiryczny (przedmiot badań) stanowią wystąpienia na forum Sejmu Rzeczypospolitej Polskiej VIII kadencji ${ }^{1}$. Szczególnie istotny dla podjętych rozważań jest nie tylko wyłaniający się z nich obraz i ocena elit politycznych - temat szeroko podejmowany w debacie publicznej, lecz także fakt, iż analizowane wypowiedzi pochodzą od podmiotów (niezależnie od tego, w jaki sposób one siebie postrzegają), które są zaliczane do elity politycznej. Są to głównie wypowiedzi posłów, a także przedstawicieli władzy wykonawczej (Prezydenta RP, ministrów i wiceministrów) oraz przedstawicieli komitetów reprezentujących obywatelskie inicjatywy ustawodawcze. Można zatem stwierdzić, iż przeprowadzone badania dotyczą oceny elit politycznych przez elity polityczne.

Wprawdzie podjęte rozważania odnoszą się do jednego z rodzajów elit, mianowicie elit politycznych, trudno jednak pominąć odwołania się do pojęcia „elita", które w literaturze przedmiotu ma wiele definicji, zróżnicowane są też kryteria podziału elit oraz koncepcje elit. Nie wchodząc głębiej w powyższe zagadnienia,

1 Analizą objęto wypowiedzi wygłoszone między 1. a 61. posiedzeniem Sejmu VIII kadencji (sesje plenarne), w którym występuje słowo „elita” w różnych jego odmianach. 
które były już przedmiotem analiz ${ }^{2}$ (nie oznacza to, że doszło do jednego, powszechnie przyjętego i zaakceptowanego sposobu rozumienia terminu „elita”, co mogłoby służyć wykreowaniu zwłaszcza jej negatywnego obrazu), warto zwrócić uwagę na rozróżnienie między potocznym i naukowym rozumieniem tego pojęcia, gdyż wydaje się, iż wypunktowanie występujących między nimi różnic ma podstawowe znaczenie dla wyjaśnienia pojawiających się często na tym tle nieporozumień. W potocznym rozumieniu elita to „grupa ludzi najlepszych pod jakimś względem w danym środowisku"3. Zygmunt Bauman zagadnienie potocznego rozumienia „elity” rozważał w sposób nieco bardziej szczegółowy, w efekcie czego wyróżnił sens neutralny i wartościujący tego pojęcia. W sensie neutralnym elitą jest zespół jednostek wyróżniający się pod jakimś uznanym za doniosły względem (np. majątku, pochodzenia czy prestiżu). W sensie wartościującym elita może być odbierana jako: 1) zjawisko pozytywne - zespół jednostek najbardziej wartościowych $\mathrm{w}$ danej grupie pod pewnym względem; 2) zjawisko negatywne (sens wartościujący pejoratywny) - zbiór jednostek odgradzających się od ogółu w poczuciu swojej wyższości (faktycznej lub domniemanej) ${ }^{4}$. Początkowo potoczne rozumienie terminu „elita” oraz to przyjmowane w naukach społecznych (szczególnie w socjologii) ${ }^{5}$ i naukach politycznych było tożsame lub bardzo zbliżone do rozumienia potocznego, lecz stopniowo ulegało ono zmianom $\mathrm{w}$ ten sposób, że komponent wartościujący ustąpił na rzecz „innych cech, zwłaszcza odnoszących się do opisu sformalizowanych ról w organizacjach politycznych i gospodarczych"6. Stąd przynależność do elity może wynikać z samego faktu sprawowania jakiejś funkcji czy zasiadania w określonym organie. Pod-

2 Zob. w szczególności następujące pozycje bibliograficzne i wskazaną w nich literaturę przedmiotu: L. Dubel, M. Niemczyk, $O$,,wieczności” koncepcji elit wladzy. Historia doktryn polityczno-prawnych $w$ retrospekcji teorii elit, [w:] Czas a trwanie idei politycznych i prawnych, red. K. Chojnicka, A. Citkowska-Kimla, W. Kozub-Ciembroniewicz, Warszawa 2008, s. 104-116; J. Sztumski, Elity - ich miejsce i rola w społeczeństwie, Katowice 1997; M. Stefaniuk, Teoria elit Vilfreda Pareta, Lublin 2001, s. 195-199; J. Nocoń, Elity polityczne. Studium interpretacji funkcjonalnej, Toruń 2004, s. 13-82; J. Potulski, Socjologia polityki, Gdańsk 2008, s. 200-208; M. Żyromski, Socjologiczna teoria elity, „Ruch Prawniczy, Ekonomiczny i Socjologiczny” 1984, nr 3, s. 267-278; G. Dutkiewicz, O pojęciu i istocie zjawiska elit, „Colloquium Wydziału Nauk Humanistycznych i Społecznych" 2012, nr 3, s. 175-184.

3 J. Wasilewski, Elita, [w:] Encyklopedia socjologii, red. Z. Bokszański, A. Kojder, t. 1, Warszawa 1998, s. 184.

4 Z. Bauman, Elita, [w:] Wielka Encyklopedia Powszechna PWN, t. 3, Warszawa 1964, s. 402-403. Zob. także: M. Stefaniuk, op. cit., s. 195-196.

5 Odnośnie do socjologicznego rozumienia pojęcia „elita” należy wskazać, że sposób jego rozumienia zależy od szkoły czy kierunku socjologicznego, przy czym Bauman (op. cit., s. 402403) wyróżnił trzy główne typy koncepcji elit: 1) ideologiczno-normatywną; 2) historiozoficzną; 3) systematyczną. Zob. także: M. Stefaniuk, op. cit., s. 195-196.

6 J. Wasilewski, op. cit., s. 184.

7 Na szczególną uwagę zasługuje podział elit według zadań, które powinno spełniać każde społeczeństwo. Stąd elity: 1) bieżącej polityki; 2) ekonomiczne, wojskowe, dyplomatyczne i nauko- 
stawą rozróżnienia elit mogą być zarówno kryteria subiektywne, kiedy bierze się pod uwagę opinie różnych grup społecznych na temat tego, kto należy do elity, jak i kryteria obiektywne, wyznaczane np. przez pozycję w strukturze społecznej ${ }^{8}$.

Przechodząc do elit politycznych, należy podkreślić, iż w Polsce zainteresowanie ich badaniem wzmogło się po 1989 r. w związku z transformacją ustrojową, ale już wcześniej je podejmowano ${ }^{9}$. U progu przemian ustrojowych badania dotyczyły przede wszystkim parlamentarzystów (elita parlamentarna), co uzasadniano względami teoretycznymi i metodologicznymi, a także elit partyjnych (delegatów na zjazdy partii politycznych $)^{10}$.

Określenie „elita polityczna”(,elita władzy”) odnosi się do osób sprawujących władzę, a więc podejmujących istotne decyzje polityczne ${ }^{11}$. Odnosząc to ogólne sformułowanie do podmiotów, których wypowiedzi na temat elit są przedmiotem niniejszych rozważań, należy zauważyć, że zdecydowana większość pochodzi od elity parlamentarnej, którą tworzą wszyscy posłowie na Sejm VIII kadencji jako część elity politycznej. Należy zgodzić się ze stwierdzeniem, iż „trudno przecenić rolę Sejmu jako miejsca formowania się warstwy polityków"12, zajmuje on bowiem trudne do przecenienia miejsce $\mathrm{w}$ procesie formowania ludzi podejmujących decyzje strategiczne dla państwa ${ }^{13}$. Parlamentarzyści są więc wyodrębnieni w ramach elity politycznej metodą pozycyjną - są to osoby zajmujące strategiczne pozycje w państwie ${ }^{14}$. Jest to elita kadencyjna ${ }^{15}$, charakteryzująca się dużym stopniem sformalizowania związanym ze społeczną selekcją oraz sposobem funkcjonowania ${ }^{16}$. Posłowie nie wyczerpują składu elity politycznej, lecz stanowią jej znaczący fragment, który „wspaniale nadaje się do studiów, zmierzających do

we; 3) autorytetu moralnego; 4) scalające społeczeństwo emocjonalnie i psychicznie. Zob. S. Keller, Elite, [w:] International Encyclopedia of the Social Sciences, ed. D.L. Sills, Vol. 5, New York 1968, s. $26-28$.

8 „Elita jest elitą, bo zajmuje pozycje, które dają jej większy wpływ na życie ogółu niż innym” - J. Żakowski, Kwit na elity, „Polityka” 2016, nr 35, s. 16.

$9 \quad$ J. Grell, Wytanianie elity władzy w Polsce Ludowej a kultura polityczna, Poznań 1989.

10 Bliżej na temat badań wraz z literaturą przedmiotu zob. M. Stefaniuk, op. cit., s. 233-251; J. Raciborski, Wprowadzenie. Elity rzadowe jako przedmiot badań, [w:] Elity rzadowe III RP 19972004. Portret socjologiczny, red. J. Raciborski, Warszawa 2006, s. 12-14. Na uwagę zasługują zwłaszcza prace: Początki parlamentarnej elity. Posłowie kontraktowego Sejmu, red. J. Wasilewski, W. Wesołowski, Warszawa 1992; Elity w Polsce, w Rosji i na Wegrzech. Wymiana czy reprodukcja?, red. I. Szelenyi, D. Treiman, E. Wnuk-Lipiński, Warszawa 1995.

11 J. Potulski, op. cit., s. 206.

12 W. Wesołowski, Wprowadzenie, [w:] Polityka i Sejm. Formowanie się elity politycznej, red. W. Wesołowski, B. Post, Warszawa 1998, s. 10.

13 Ibidem.

14 J. Potulski, op. cit., s. 206.

15 J. Sztumski, op. cit., s. 44.

16 Ibidem, s. 52. 
łączenia perspektywy grupowo-strukturalnej i instytucjonalnej"17. Owa elita parlamentarna to zarówno elita reprezentująca większość parlamentarną (siły rządzące), jak i elita opozycyjna. Oprócz parlamentarzystów o elitach wypowiadali się również inni przedstawiciele elity rządzącej - Prezydent oraz osoby składające się na elitę rządową (członkowie Rady Ministrów). Ta część elity politycznej, która „definiowana jest jako grupa osób sprawujących władzę wykonawczą"18, jest świadomie tworzona $\mathrm{i}$ - podobnie jak elita parlamentarna - jest wyodrębniona metodą pozycyjną ${ }^{19}$. Należy przy tym zauważyć, iż przynależność do elity parlamentarnej i rządowej może się pokrywać np. wtedy, gdy poseł zostanie powołany na stanowisko ministra. W niewielkim stopniu w niniejszym opracowaniu zostaną zaprezentowane wypowiedzi osób, które można zaliczyć do elity politycznej, ale nierządzącej (np. przedstawiciele komitetów inicjatyw ustawodawczych), gdyż i one należą do elity politycznej, reprezentują bowiem pozaparlamentarne partie polityczne, związki zawodowe czy grupy interesów.

Przystępując do analizy wypowiedzi wymienionych wyżej podmiotów na temat elit politycznych wygłaszanych na forum niższej izby parlamentu, należy szczególnie mocno podkreślić rolę, jaką mogą one odgrywać dla wizerunku owych elit. Elity polityczne, a zwłaszcza elity rządzące, pełnią wśród wielu różnorodnych funkcji również funkcję opiniotwórczą. Wypowiedzi na forum Sejmu mogą wpływać na sposób postrzegania elit przez „,zwykłych ludzi”. Szczególnie krytyczne stanowisko wobec niektórych rodzajów elit politycznych i ich przedstawicieli może doprowadzić do przekonania, iż taki jest ich rzeczywisty obraz niezależnie od tego, czy jest on prawdziwy czy też nie. Jest to tym bardziej istotne, gdyż ocenianie polityków (w tym parlamentarzystów) przez społeczeństwo jest od wielu lat niezmiennie surowe ${ }^{20}$.

Z badań opinii społecznej wynika, iż społeczeństwo polskie uznaje polityków za elitę. Badacze w sposób przekonywujący uzasadnili prowadzone sondaże stwierdzeniem, iż „opinie o elitach mówią wiele o stanie zbiorowej świadomości, o widzeniu spraw państwa, o aspiracjach i ocenie własnych, jednostkowych możliwości" ${ }^{21}$. W badaniu z 2017 r. zapytano, kto w Polsce należy do elity - politycy znaleźli się na trzecim miejscu (69\%, podobnie jak lekarze), za osobami najbogatszymi (78\%), znanymi artystami, celebrytami (72\%), właścicielami mediów,

17 W. Wesołowski, op. cit., s. 9.

18 J. Raciborski, op. cit., s. 9.

19 J. Potulski, op. cit., s. 206.

20 W badaniach dotyczących prestiżu zawodów czy uczciwości i rzetelności zawodowej politycy znajdują się „,tradycyjnie” na ostatnim miejscu spośród badanych zawodów, a przedostatnie zajmuje wyodrębniona spośród polityków kategoria - posłowie na Sejm. Szczegółowe dane zob. Społeczne oceny uczciwości i rzetelności zawodowej, „CBOS. Komunikat z Badań” 2016, nr 34, www.cbos.pl/SPISKOM.POL/2016/K_034_16.PDF [dostęp: 26.05.2018].

21 M. Janicki, Elita znika, „Polityka”, 4.07.2017, www.polityka.pl/tygodnikpolityka/kraj/1710972,1,kto-w-polsce-nalezy-do-elity.read [dostęp: 26.05.2018]. 
szefami stacji telewizyjnych, gazet (71\%), a przed naukowcami (62\%), przedsiębiorcami (59\%), oficerami wojska i policji (54\%), księżmi (48\%), radnymi (39\%), nauczycielami $(36 \%)^{22}$. Należy jednak mocno zaakcentować, iż ocena polskiej elity politycznej jest zdecydowanie negatywna, gdyż $59 \%$ badanych oceniło ją źle, tylko $24 \%$ - dobrze, a $17 \%$ respondentów trudno było odpowiedzieć na to pytanie ${ }^{23}$.

\section{ELITA POLITYCZNA I JEJ CECHY}

Z wypowiedzi sejmowych wynika, iż elity polityczne odróżniano od innych rodzajów elit, niemających bezpośredniego związku z procesem sprawowania władzy. Jest to ujęcie nawiązujące do poglądów jednego ze współtwórców socjologicznej teorii elit i badacza, który wprowadził pojęcie „elita” do dyskursu naukowego - Vilfredo Pareto. Twierdził on, iż elity można wyróżnić w każdej sferze ludzkiej działalności, a stanowią je ci wszyscy, którzy mają w danej dziedzinie najwyższe wskaźniki osiągnięć ${ }^{24}$. Pareto uważał, iż należy rozróżnić tych, którzy bezpośrednio odgrywają znaczącą rolę w rządzeniu (elita rządząca), oraz tych, którzy czynią to pośrednio (elita nierządząca) ${ }^{25}$. Ze względu na tytuł i rozmiary niniejszego artykułu w dalszej części uwaga będzie skupiona na elicie politycznej; pozostałe rodzaje elit pojawiające się w wypowiedziach sejmowych (jak np. elita administracji, elita skarbowa czy elita naukowa) zostaną poddane analizie w kolejnym opracowaniu.

Odnośnie do odpowiedzi na pytanie, kto stanowi elitę polityczną w opinii osób występujących na forum Sejmu, można znaleźć potwierdzenie, iż są to parlamentarzyści bez względu na to, jaką reprezentują partię polityczną. Kiedy Prezes Rady Ministrów wskazuje na podmiot, który ma dbać o bezpieczeństwo Polski, to powierza to zadanie polskim elitom politycznym: „To jest nasze zadanie, to jest zadanie elit politycznych, które siedzą na tej sali" ${ }^{26}$. Polskie elity były nazywa-

22 Sondaż przeprowadzony na zlecenie „Polityki” przez pracownię Kantar Public w dniach 9-14 czerwca 2017 r. na próbie 1051 Polaków w wieku 15 lat i więcej za pomocą wywiadów bezpośrednich wspomaganych komputerowo. Dane z badań za: M. Janicki, op. cit. W tych samych badaniach na pytanie, czym jest elita w Polsce, 50\% badanych odpowiedziało, iż są to ludzie bogaci i wpływowi, 20\% - to ludzie zasługujący na szacunek z racji intelektu, kompetencji zawodowych i postawy moralnej, 19\% - to grupa społeczna, która zdobyła majątek w okresie transformacji i wykorzystuje swoją pozycję do realizacji własnych interesów.

23 Ibidem.

24 V. Pareto, Uczucia i działania. Fragmenty socjologiczne, wyb., wstęp i red. A. Kojder, Warszawa 1994, s. 278.

25 Ibidem.

26 Wystąpienie Prezes Rady Ministrów Beaty Szydło, [w:] Spraw. sten. z 42. pos. Sejmu RP w dniu 7 czerwca 2017 r. (drugi dzień obrad), Warszawa 2017, s. 56. 
ne również polską klasą polityczną ${ }^{27}$. Tego typu terminologia nawiązuje z kolei do koncepcji elitystycznej Gaetano Moski ${ }^{28}$. Podnoszono, aby nie utożsamiać elit z narodem, ponieważ elita „to nie suweren, czyli nie naród” i w ważnych sprawach należy rozmawiać $\mathrm{z}$ narodem, a nie $\mathrm{z}$ elitami ${ }^{29}$. Jednocześnie bardzo stanowczo aktualnie rządzący odcinają się od uznawania siebie za rząd elit: „My jesteśmy rządem reprezentującym zwykłych Polaków. Nie jesteśmy rządem elit”30. Powyższe uprawnia do stwierdzenia, iż zaakceptowanie przez rządzących, iż stanowią elitę (przynajmniej w pozycyjnym rozumieniu), następuje przy równoczesnym zaprzeczeniu, iż rząd ten działa dla elit. Opozycji natomiast zarzucano, że nie potrafi tego faktu zaakceptować, w przeciwieństwie do obywateli, którzy powinni mieć pewność, że rządy znajdują się w dobrych rękach: „Ja wiem, że to boli, ale nie jesteśmy rządem elit" ${ }^{\prime 1}$.

W wystąpieniach sejmowych wskazywano, jakimi cechami powinna się charakteryzować elita polityczna, przy czym tego rodzaju wypowiedzi pochodzą zarówno od przedstawicieli opcji rządzącej, jak i opozycji. Po pierwsze, powinna dawać obywatelom i różnym grupom społecznym dobry przykład, być wzorem dla różnych grup społecznych ${ }^{32}$. Po drugie, powinna składać się z ludzi uczciwych, aby każdy obywatel miał przekonanie, że władza jest w rękach ludzi, którzy zapewnią im godne życie i prawo do decydowania o sobie ${ }^{33}$. Po trzecie, elita powinna stale pamiętać o potrzebach własnych obywateli, nie myśleć o samej sobie, pod rygorem obalenia jej przez zwykłych ludzi, czego przykład miał miejsce w Wielkiej Brytanii ${ }^{34}$. Po czwarte, do obowiązków wszystkich elit politycznych zaliczono szacunek do wyroków Trybunału Konstytucyjnego, a ich wdrażanie jest traktowane jako bezpośredni obowiązek rządu ${ }^{35}$.

27 Wystąpienie posła Andrzeja Maciejewskiego, [w:] Spraw. sten. z 36. pos. Sejmu RP w dniu 24 lutego 2017 r. (drugi dzień obrad), Warszawa 2017, s. 219.

${ }_{28}$ Zob. bliżej: M. Stefaniuk, op. cit., s. 75-76.

29 Wystąpienie posła Jana Szewczaka, [w:] Spraw. sten. z 57. pos. Sejmu RP w dniu 19 lipca 2017 r. (drugi dzień obrad), Warszawa 2017, s. 212.

30 Wystąpienie Prezes Rady Ministrów Beaty Szydło, [w:] Spraw. sten. z 53. pos. Sejmu RP w dniu 7 grudnia 2017 r. (drugi dzień obrad), Warszawa 2017, s. 146.

31 Ibidem.

32 Wystąpienie posła Marka Rucińskiego, [w:] Spraw. sten. z 28. pos. Sejmu RP w dniu 19 października 2016 r. (pierwszy dzień obrad), Warszawa 2016, s. 107.

33 Wystąpienie Prezes Rady Ministrów Beaty Szydło, [w:] Spraw. sten. z 53. pos. Sejmu RP $w$ dniu 7 grudnia 2017 r. (drugi dzień obrad), s. 146.

34 Wystąpienie posła Rafała Wójcikowskiego, [w:] Spraw. sten. z 23. pos. Sejmu RP w dniu 20 lipca 2016 r. (trzeci dzień obrad), Warszawa 2016, s. 357.

35 Wystąpienie posła Witolda Zembaczyńskiego, [w:] Spraw. sten. z 14. pos. Sejmu RP w dniu 18 marca 2016 r. (trzeci dzień obrad), Warszawa 2016, s. 270. 


\section{ELITA NARODOWA}

W analizowanych wystąpieniach na forum Sejmu coraz częściej pojawia się kategoria elity narodowej (czy elity narodu). Pojęcie to używane jest albo zamiennie z określeniem ,elita polityczna”36, albo występuje samodzielnie, wyraźnie osłabiając negatywne skojarzenia związane z pojęciem „elita”. Do elity narodowej (w domyśle - prawdziwej elity) zostały zaliczone konkretne postaci polskiej sceny politycznej - Prezes PiS oraz Premier, ale też parlamentarzyści ${ }^{37}$. Szczególne miejsce jednak w kategorii elity narodowej zajmują osoby związane z Prezydentem Lechem Kaczyńskim, których postawa wobec imperialnej polityki Federacji Rosyjskiej kosztowała życie, gdyż pod Smoleńskiem „doszło do zagłady polskiej elity narodowej”38. Przeciwko sformułowaniu o „zagładzie” protestowała opozycja, uznając, że takie stwierdzenie to „wyjaśnienie czy próba uzupełnienia [...] kłamstwa smoleńskiego" ${ }^{39}$.

Formację elit narodowych powierzano polskim uczelniom, które powinny być wzmacniane, by przezwyciężyć drenaż najzdolniejszych umysłów Polski ${ }^{40}$. Jednocześnie niejednokrotnie podnoszono, że potrzebne jest dofinansowanie oświaty na wszystkich poziomach edukacji ${ }^{41}$. Kształtowanie elit przekazywano również konkretnym organizacjom (np. Związkowi Harcerstwa Rzeczypospolitej), uznając to za szczególnie potrzebne „w obliczu miałkości intelektualnej wielu, słabości i wahliwości postaw aksjologiczno-normatywnych oraz tchórzliwości w podejmowaniu zadań i braniu za nie odpowiedzialności” ${ }^{42}$. Miałyby to być zatem elity wyposażone w cenne zalety ducha, o odpowiednich walorach moralnych. Wydaje się, iż elita narodowa ma być w założeniu tą „zdrową” elitą, która przywróci temu pojęciu właściwe, pozytywne znaczenie.

36 Wystąpienie Ministra Obrony Narodowej Antoniego Macierewicza, [w:] Spraw. sten. z 28. pos. Sejmu RP..., s. 185.

37 Wystąpienie posła Tadeusza Cymańskiego [w:] Spraw. sten. z 51. pos. Sejmu RP w dniu 9 listopada 2017 r. (drugi dzień obrad), Warszawa 2017, s. 184.

38 Wystąpienie Ministra Obrony Narodowej Antoniego Macierewicza, [w:] Spraw. sten. z 29. pos. Sejmu RP w dniu 3 listopada 2016 r. (pierwszy dzień obrad), Warszawa 2016, s. 146.

39 Wystąpienie posła Stefana Niesiołowskiego, [w:] Spraw. sten. z 29. pos. Sejmu RP w dniu 3 listopada 2016 r. (pierwszy dzień obrad), s. 153.

40 Wystąpienie Prezesa Rady Ministrów Ministra Rozwoju i Finansów Mateusza Morawieckiego, [w:] Spraw. sten. z 54. pos. Sejmu RP w dniu 12 grudnia 2017 r. (pierwszy dzień obrad), Warszawa 2017, s. 9.

${ }_{41}$ Wystąpienie poseł Małgorzaty Zwiercan, [w:] Spraw. sten. z 28. pos. Sejmu RP..., s. 36.

42 Wystąpienie posła Jacka Kurzępy, [w:] Spraw. sten. z 61. pos. Sejmu RP w dniu 13 kwietnia 2018 r. (trzeci dzień obrad), Warszawa 2018, s. 271. 


\section{KRYTYKA „TAK ZWANYCH” ELIT KOMUNISTYCZNYCH}

W wystąpieniach sejmowych dosyć często powoływano się na elity historycz$\mathrm{ne}^{43}$. Sięgano przy tym nawet do dość odległych czasów, najczęściej wypowiadając się o elitach wówczas funkcjonujących w sposób pozytywny. Powyższe sprawia wrażenie jakby określenie jakiejś grupy mianem elity, jeżeli dotyczy przeszłości, nadaje jej (w domyśle) przydomek ,prawdziwej” elity i uwalnia od negatywnych skojarzeń, które współcześnie może wywoływać (i często wywołuje) to pojęcie. Do docenionych zostały zaliczone elity świeckie i duchowne, które przyczyniły się do powstania Konstytucji $3 \mathrm{Maja}^{44}$, a także elity funkcjonujące w okresie zaborów i rola, którą odegrały po odzyskaniu niepodległości ${ }^{45}$. Podkreślano, iż w okresie międzywojennym istniała w Polsce elita, która rozpoznawała potrzeby polskiego narodu ${ }^{46}$. Przypominano też o tragicznych losach polskich elit w okresie II wojny światowej ${ }^{47}$, podczas której doszło do „wytrzebienia” elit polskiego narodu ${ }^{48}$, ich „wytępienia”,49, gdy na polskich elitach dokonywano egzekucji ${ }^{50}$ bądź wywożono ją na zesłanie ${ }^{51}$.

W zasadzie jedynymi elitami z przeszłości, do których odnoszono się w sposób zdecydowanie negatywny, były elity komunistyczne, określane również jako „tak zwane" elity. Mimo ich pejoratywnej oceny uważano, że należy je poznawać i o nich pisaćs2.

43 W niniejszym opracowaniu tym pojęciem są określane elity sprzed $1989 \mathrm{r}$.

44 Uchwała Sejmu Rzeczypospolitej Polskiej z dnia 29 kwietnia 2016 r. w sprawie uczczenia twórców Konstytucji 3 Maja, [w:] Spraw. sten. z 17. pos. Sejmu RP w dniu 29 kwietnia 2016 r. (trzeci dzień obrad), Warszawa 2016, s. 206.

45 Wystąpienie poseł Joanny Schmidt, [w:] Spraw. sten. z 29. pos. Sejmu RP w dniu 3 listopada 2016 r. (pierwszy dzień obrad), s. 147; Wystąpienie Prezydenta Rzeczypospolitej Polskiej Andrzeja Dudy, [w:] Spraw. sten. z pos. Zgromadzenia Narodowego w dniu 5 grudnia 2017 r., Warszawa 2017, s. 7.

46 Wystąpienie posła Sylwestra Chruszcza, [w:] Spraw. sten. z 43. pos. Sejmu RP w dniu 8 czerwca 2017 r. (drugi dzień obrad), Warszawa 2017, s. 258.

47 Wystąpienie poseł Lidii Burzyńskiej, [w:] Spraw. sten. z 43. pos. Sejmu RP w dniu 8 czerwca 2017 r. (drugi dzień obrad), s. 310; Wystąpienie Sekretarza Stanu w Ministerstwie Kultury i Dziedzictwa Narodowego Jarosława Sellina, [w:] Spraw. sten. z 17. pos. Sejmu RP..., s. 54; Wystąpienie posła Jana Kiliana, [w:] Spraw. sten. z 39. pos. Sejmu RP w dniu 7 kwietnia 2017 r. (trzeci dzień obrad), Warszawa 2017, s. 358; Wystąpienie posła Piotra Babinetza, [w:] Spraw. sten. z 6. pos. Sеjmu RP w dniu 22 grudnia 2015 r. (drugi dzień obrad), Warszawa 2015, s. 126.

48 Wystąpienie posła Roberta Winnickiego, [w:] Spraw. sten. z 59. pos. Sejmu RP w dniu 6 marca 2018 r. (czwarty dzień obrad), Warszawa 2018, s. 293.

49 Wystąpienie poseł Bernadetty Krynickiej, [w:] Spraw. sten. z 61. pos. Sejmu RP ..., s. 217.

50 Wystąpienie poseł Lidii Burzyńskiej, [w:] Spraw. sten. z 43. pos. Sejmu RP w dniu 8 czerwca 2017 r. (drugi dzień obrad), s. 310.

51 Wystąpienie posła Mieczysława Kazimierza Baszko, [w:] Spraw. sten. z 11. pos. Sejmu RP w dniu 10 lutego 2016 r. (drugi dzień obrad), Warszawa 2016, s. 240.

52 Wystąpienie Prezesa Instytutu Pamięci Narodowej - Komisji Ścigania Zbrodni przeciwko Narodowi Polskiemu Łukasza Kamińskiego, [w:] Spraw. sten. z 23. pos. Sejmu RP w dniu 21 lipca 2016 r. (pierwszy dzień obrad), Warszawa 2016, s. 67. 
Elity komunistyczne były często przywoływane w kontekście zarzutów stawianych rządom po 1989 r., które nie rozliczyły się z ludźmi sprawującymi władzę w okresie Polski Ludowej. Dotyczyło to pobieranych przez osoby należące do komunistycznej elity nieuzasadnionych i wygórowanych świadczeń emerytalnych, co skłaniało m.in. do postawienia pytania: „Co to za kraj, w którym bohaterowie żyją w biedzie, a ich oprawcy pobierają sowite emerytury [...]?”. Ponadto elity III RP (co jeszcze poszerza liczbę stawianych im zarzutów, o których niżej będzie mowa) nie potrafiły rozliczyć się ze zdrajcami ojczyzny - tu „największym przykładem” był Wojciech Jaruzelski, którego „elity rządzące z Platformy na czele z prezydentem Komorowskim żegnały z honorami" ${ }^{53}$, choć jest to ewidentny przykład osoby, która zasługuje na historyczne potępienie ${ }^{54}$. Dopiero objęcie władzy przez Prawo i Sprawiedliwość umożliwiło procedowanie nad ustawą o pozbawieniu stopni wojskowych osób i żołnierzy rezerwy, którzy w latach 1943-1990 swoją postawą sprzeniewierzyli się polskiej racji stanu ${ }^{55}$.

\section{KRYTYKA ELIT UNII EUROPEJSKIEJ}

Wśród współczesnych elit politycznych, o których była mowa, w analizowanych wystąpieniach szczególnie rozbudowana krytyka odnosiła się do elit Unii Europejskiej i III Rzeczypospolitej Polskiej. Można nawet stwierdzić, że właśnie tych kwestii dotyczyła znaczna część wypowiedzi na temat elit w polskim Sejmie, co wiązało się głównie z tym, aby poddawać je negatywnej ocenie.

Elity Unii Europejskiej, określane zazwyczaj w skrócie jako „elity brukselskie", były uznawane jako jedna z trzech sił istniejących obecnie w UE obok uchodźców i państw narodowych. Przyznaje się im przydomek elit lewicowo-liberalnych, a ich dyktat jest traktowany (obok najazdu obcych imigrantów) wręcz jako ,plaga" 56 .

Na dość długiej liście zarzutów wobec elit brukselskich na pierwszym miejscu znajduje się ich oderwanie od społeczeństwa. Trudne położenie, w jakim znalazła się Unia, było spowodowane różnego rodzaju inicjatywami, u których podstaw leżały „motywy ideologiczne, a nie dobro społeczeństw Unii” ${ }^{57}$. Powyższe doprowadziło do tego, iż „Powstała przepaść między elitami europejskimi i obywatelami tracącymi poczucie, że mają realny wpływ na to, co dzieje się z ich

53 Wystąpienie posła Waldemara Andzla, [w:] Spraw. sten. z 59. pos. Sejmu RP ..., s. 282.

54 Wystąpienie posła Michała Jacha, [w:] Spraw. sten. z 59. pos. Sejmu RP ..., s. 271.

55 Wystąpienie posła Waldemara Andzla, [w:] Spraw. sten. z 59. pos. Sejmu RP..., s. 282.

56 Wystapienie posła Roberta Winnickiego, [w:] Spraw. sten. z 9. pos. Sejmu RP $w$ dniu 28 stycznia $2016 r$. (drugi dzień obrad), Warszawa 2016, s. 185.

57 Wystąpienie Ministra Spraw Zagranicznych Witolda Waszczykowskiego, [w:] Spraw. sten. z 35. pos. Sеjmu RP w dniu 9 lutego 2017 r. (drugi dzień obrad), Warszawa 2017, s. 112. 
krajami i z projektem integracyjnym" 58 . Owe elity, zamiast odbudowywać swoje relacje $\mathrm{z}$ obywatelami, kwestionowały wydane im negatywne oceny, a więc nie reagowały w sposób prawidłowy, nie wykazywały refleksji nad tą sytuacją ${ }^{59}$. Wydarzenia, jakie miały miejsce w Wielkiej Brytanii, z kolei pokazują, iż obywatele w referendum „obalili elitę, establishment brytyjski i pokazali im, że nie życzą sobie dalszego spoufalania się z elitami Unii Europejskiej"

Elity europejskie krytykowano też za to, że nie działały na rzecz dobra obywateli, lecz głównie na rzecz elit, układów biznesowych, korporacji międzynarodowych oraz samych siebie ${ }^{61}$. Co więcej, łamały zasady zawarte w traktatach (np. w kwestiach dotyczących wykorzystywania zasobów naturalnych dla zagwarantowania bezpieczeństwa energetycznego), co prowadziło do dyskryminacji takich krajów, jak Polska, gdzie gospodarka w znacznym stopniu jest oparta na węglu ${ }^{62}$.

Ponadto wskazywano, że elity europejskie nie dbają o dobro swoich obywateli w sferze bezpieczeństwa przez to, iż zgadzają się na przyjmowanie uchodźców. Po zamachach terrorystycznych w Manchesterze ówczesna premier rządu RP Beata Szydło podkreślała, iż ma odwagę ,zadać elitom politycznym w Europie pytanie: Dokąd zmierzacie? Dokąd zmierzasz, Europo? Powstań z kolan i obudź się z letargu, bo w przeciwnym razie codziennie będziesz opłakiwała swoje dzieci" ${ }^{\prime 63}$. Mimo że przynależność do Unii Europejskiej to przede wszystkim branie na siebie odpowiedzialności, to jednak nie potrafią jej przyjąć elity polityczne w Brukseli, ponieważ są ,zaślepione poprawnością polityczną i wystraszone" ${ }^{64}$. Co więcej, nie dostrzegają niebezpieczeństw związanych z przyjmowaniem uchodźców z perspektywy „swoich szklanych biurowców”65. Jednocześnie elity polityczne Europy nie chcą zrozumieć, że Polska taką odpowiedzialność na siebie przyjęła i przyjmuje imigrantów zza naszej wschodniej granicy ${ }^{66}$.

Elity brukselskie lekceważą też głos Europejczyków, którym „każe się właśnie w imię politycznej poprawności myśleć tak samo”, oni zaś „są zniecierpliwieni i coraz bardziej rozczarowani kierunkiem, w którym idzie nie Europa,

58 Ibidem.

59 Ibidem.

60 Wystąpienie posła Rafała Wójcikowskiego, [w:] Spraw. sten. z 23. pos. Sejmu RP w dniu 21 lipca 2016 r. (trzeci dzień obrad), s. 357.

${ }_{61}$ Wystąpienie poseł Izabeli Kloc, [w:] Spraw. sten. z 38. pos. Sejmu RP w dniu 23 marca 2017 r. (drugi dzień obrad), Warszawa 2017, s. 208.

62 Ibidem.

${ }^{63}$ Wystąpienie Prezes Rady Ministrów Beaty Szydło, [w:] Spraw. sten. z 42. pos. Sejmu RP..., s. 55.

64 Ibidem.

65 Wystąpienie posła Sylwestra Chruszcza, [w:] Spraw. sten. z 31. pos. Sejmu RP w dniu 2 grudnia 2016 r. (czwarty dzień obrad), Warszawa 2016, s. 363.

${ }_{66}$ Wystąpienie poseł Małgorzaty Gosiewskiej, [w:] Spraw. sten. z 10. pos. Sejmu RP w dniu 29 stycznia 2016 r. (drugi dzień obrad), Warszawa 2016, s. 84. 
ale europejskie elity”67. Wspomniany wyżej „lewicowo-liberalny” charakter elit powoduje, iż forsują one jeden określony typ polityczny i kulturowy, który ma obowiązywać na całym obszarze ich wpływów. „To jest po prostu kolonializm kulturowy, polityczny, ideologiczny [...]"68.

To brukselskie elity i opozycja próbowały wmówić Polakom, iż w naszym kraju istnieje problem z nazistami, a tymczasem podczas gdy „w Polsce takie kreatury muszą chować się po lasach, w Niemczech maszerują przez centrum Berlina" ${ }^{69}$.

Fakt sprawowania przez Polaka wysokiej funkcji w strukturach europejskich nie korygował w żadnym stopniu krytycznego stosunku do elit w Brukseli. Wręcz przeciwnie, o przewodniczącym Rady Europejskiej wypowiadano się jako o osobie wysługującej się Europie, zakładającej „marynarki brukselskim elitom”, a nawet wprost określano go jako „lokaja Europy”70. Surowo też oceniano Komisję Europejską i jej przewodniczącego, wskazując, że „Są nadmiernie upolitycznieni, skupieni na własnym funkcjonowaniu, $[. .$.$] nie liczą się z dobrem społeczeństwa,$ ale realizują plany ideologiczne elity europejskiej"'71.

W nielicznych wystąpieniach opozycji dających odpór zarzutom stawianym elitom w Brukseli przypominano, że ramy instytucjonalne, które są poddawane krytyce przez rządzących obecnie w Polsce, opierają się na Traktacie lizbońskim, za którym opowiedzieli się zmarły Prezydent Lech Kaczyński oraz Jarosław Kaczyński ${ }^{72}$.

Pomimo tak krytycznych ocen elit w Brukseli jednocześnie była podnoszona potrzeba posiadania wśród nich ,znajomości”. Osobą, która spełnia tego rodzaju oczekiwania, jest Premier Mateusz Morawiecki, który z jednej strony „Dobrze zna europejskie elity polityki i biznesu" ${ }^{\prime \prime 3}$, ale z drugiej różni się od nich „przywiązaniem do historii i tradycji własnego narodu, religijnością, szacunkiem dla chrześcijańskich fundamentów europejskiej kultury"74.

Na podstawie powyższych rozważań można stwierdzić, że elity brukselskie jawią się jako oderwane od rzeczywistości, są źle oceniane w państwach narodowych, działają wyłącznie w swoim interesie lub interesie grup z nimi bezpośrednio powiązanych, łamią zasady traktatowe, dyskryminują niektóre państwa

67 Wystąpienie Prezes Rady Ministrów Beaty Szydło, [w:] Spraw. sten. z 23. pos. Sejmu RP $w$ dniu 20 lipca 2016 r. (drugi dzień obrad), Warszawa 2016, s. 350.

68 Wystąpienie posła Roberta Winnickiego, [w:] Spraw. sten. z 25. pos. Sejmu RP w dniu 14 grudnia 2016 r. (drugi dzień obrad), Warszawa 2016, s. 213.

${ }^{69}$ Wystąpienie Ministra Spraw Wewnętrznych i Administracji Joachima Brudzińskiego, [w:] Spraw. sten. z 57. pos. Sejmu RP..., s. 28.

70 Wystąpienie Prezes Rady Ministrów Beaty Szydło, [w:] Spraw. sten. z 45. pos. Sejmu RP $w$ dniu 12 lipca 2017 r. (pierwszy dzień obrad), Warszawa 2017, s. 28-29. Jako źródło określenia „lokaj Europy” zostali powołani internauci.

71 Wystąpienie poseł Izabeli Kloc, [w:] Spraw. sten. z 35. pos. Sejmu RP..., s. 138.

72 Wystąpienie posła Michała Kamińskiego, [w:] Spraw. sten. z 35. pos. Sejmu RP..., s. 144.

73 Wystąpienie posła Ryszarda Terleckiego, [w:] Spraw. sten. z 54. pos. Sejmu RP..., s. 15.

74 Ibidem. 
(w tym Polskę), nie zapewniają bezpieczeństwa swoim obywatelom, a co za tym idzie są nieodpowiedzialne, oczekują od przedstawicieli niektórych państw (w tym Polski), aby się im wysługiwali nawet wówczas, gdy ich obywatele zostali dopuszczeni do ważnych funkcji w UE.

\section{KRYTYKA ELIT III RZECZYPOSPOLITEJ POLSKIEJ}

Jeszcze dłuższa jest lista oskarżeń wysuwanych w kierunku „elit III RP”. Wystawiona im negatywna ocena dotyczyła również elit z początków transformacji, określanych jako ,elity okrągłostołe” czy „demoliberalne"75. Podawano w wątpliwość, czy rok 1989 - przywołany w Preambule Konstytucji RP z dnia 2 kwietnia 1997 r. - faktycznie był rokiem odzyskania suwerenności i otworzył możliwości dla demokracji i stanowienia o losach Ojczyzny czy też był momentem, w którym „ułożyły się okrągłostołowe elity"76. Poza tym pojawiały się oskarżenia pod adresem elity solidarnościowej, która w 1989 r. uważała, że należy „dogadywać się z ludźmi Moskwy", co porównano do postawy lojalizmu Polaków w okresie zaborów wobec caratu ${ }^{77}$. Generalnie do elity z początku lat 90 . XX w. odnoszono się w sposób pejoratywny. Mimo ostrzeżeń Jana Pawła II „Polska została podporządkowana egoistycznym interesom rodzącej się oligarchii. Nie powstała elita ducha, nie oparliśmy życia społecznego na trwałych zasadach moralnych: solidarności, dobra wspólnego, pomocniczości. Hasłem tamtych czasów stało się: pierwszy milion trzeba ukraść”78. Chociaż elity - wówczas „nowe”, bo nastąpiły po okresie Polski Ludowej - chętnie fotografowały się z Papieżem, to jednak nie zamierzały budować Polski na „moralnym fundamencie wartości i prawdy”79. Co więcej, dojście do władzy elit III RP doprowadziło do tego, iż część osób, które walczyły o wolną Polskę, nie uzyskała tej wolności po obradach Okrągłego Stołu.

Z całą mocą muszę powiedzieć, że dla „Solidarności Walczącej” wolność nie zaczęła się po okrągłym stole. Kręgi, które doszły do władzy w roku 1989, jak też elity uprzywilejowane w następstwie kontraktu zawartego z byłymi właścicielami Polski Ludowej, uczyniły wszystko, by o „Solidarności Walczącej” zapomniano ${ }^{80}$.

75 Wystąpienie posła Roberta Winnickiego, [w:] Spraw. sten. z 4. pos. Sejmu RP w dniu 10 grudnia 2015 r. (drugi dzień obrad), Warszawa 2015, s. 153.

76 Wystąpienie posła Tomasza Jaskóły, [w:] Spraw. sten. z 11. pos. Sejmu RP ..., s. 2016.

77 Wystąpienie posła Tomasza Jaskóły, [w:] Spraw. sten. z 8. pos. Sejmu RP w dniu 13 stycznia 2016 r. (pierwszy dzień obrad), Warszawa 2016, s. 79.

78 Wystąpienie posła Stefana Romeckiego, [w:] Spraw. sten. z 20. pos. Sejmu RP w dniu 9 czerwca 2016 r. (drugi dzień obrad), Warszawa 2016, s. 366.

79 Ibidem, s. 365.

80 Wystąpienie poseł Małgorzaty Zwiercan, [w:] Spraw. sten. z 44. pos. Sejmu RP w dniu 22 czerwca 2017 r. (trzeci dzień obrad), Warszawa 2017, s. 329. 
Do zarzutów stawianych wszystkim, którzy składają się na łączne określenie „elity III RP”, należy przede wszystkim wykluczanie niektórych grup społecznych, a zadaniem nowej władzy jest odwrócenie tego, co stało się w poprzednim okresie, oraz przywrócenie godności ${ }^{81}$ wykluczonym i pogardzanym ${ }^{82}$.

Szczególnie surowo i jednoznacznie negatywnie przedstawiciele elity rządzącej wybranej w 2015 r. ocenili okres rządów swoich bezpośrednich poprzedników, mianowicie koalicji PO-PSL. W ich ujęciu wówczas funkcjonowało „Państwo sytych kręgów władzy, gdzie elita rządząca ma się dobrze, ale oby-

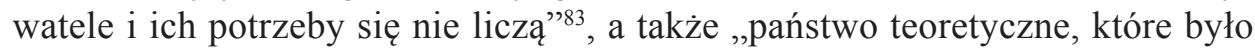
silne wobec słabych, ale słabe wobec silnych" ${ }^{\text {" }}$. Była to elita, które nie wzięła odpowiedzialności za swoje działania, wygodna, dbająca wyłącznie o swoje interesy i przyjemności ${ }^{85}$. Cechami rządów Platformy i PSL-u były: egoizm, marnotrawstwo, pogarda ${ }^{86}$. Powyższe przejawiało się w szczególności w odniesieniu do spraw gospodarczych, bo nawet dobre wskaźniki gospodarcze służyły „dobrym humorom elit warszawskich i paru innych" ${ }^{87}$, podczas gdy powinny one przynieść dobrobyt całemu polskiemu społeczeństwu ${ }^{88}$. Z powyższym wiąże się obarczanie elit poprzedniego okresu winą za wyjazdy Polaków za granicę w poszukiwaniu godnej pracy ${ }^{89}$. To elity po 1989 r. ponoszą odpowiedzialność za wyprzedaż polskiego majątku narodowego, ,często za bezcen, w atmosferze gigantycznych afer i skandali" ${ }^{90}$, co powoduje, że nie mają prawa udzielać rad obecnie rządzącym. Elitom PO i PSL zarzucano też konsumpcyjne nastawienie na samych siebie, podczas gdy wypracowane przez społeczeństwo pieniądze mogłyby zostać przeznaczone na inne, ważne społecznie cele, a nie życie ,pewnych elit" ponad $\operatorname{stan}^{91}$.

Elity III RP obciążano dodatkowo bardzo poważnym oskarżeniem odnoszącym się do tzw. kłamstwa wołyńskiego, które powinno być ścigane przez prawo.

81 Wystąpienie posła Pawła Szefernakera, [w:] Spraw. sten. z 29. pos. Sejmu RP w dniu 4 listopada 2016 r. (drugi dzień obrad), Warszawa 2016, s. 211.

82 Ibidem.

83 Wystąpienie Prezes Rady Ministrów Beaty Szydło, [w:] Spraw. sten. z 18. pos. Sejmu RP w dniu 11 maja 2016 r. (pierwszy dzień obrad), Warszawa 2016, s. 12.

${ }^{84}$ Ibidem.

85 Ibidem.

86 Ibidem, s. 13.

87 Wystąpienie Wiceprezesa Rady Ministrów Ministra Rozwoju i Finansów Mateusza Morawieckiego, [w:] Spraw. sten. z 49. pos. Sejmu RP w dniu 10 października 2017 r. (pierwszy dzień obrad), Warszawa 2017, s. 15.

88 Ibidem.

89 Ibidem, s. 80.

90 Wystąpienie posła Jana Szewczaka, [w:] Spraw. sten. z 46. pos. Sejmu RP w dniu 20 lipca 2017 r. (drugi dzień obrad), Warszawa 2017, s. 212.

${ }_{91}$ Wystąpienie poseł Anny Paluch, [w:] Spraw. sten. z 37. pos. Sejmu RP w dniu 8 marca 2017 r. (pierwszy dzień obrad), Warszawa 2017, s. 96. 
Było ono „kolportowane przez elity III Rzeczypospolitej”, wydając „haniebne owoce" $"$.

Brak dbałości przez elity III RP o interes obywateli odnosił się nie tylko do polityki wewnętrznej, ale i do polityki międzynarodowej, która „musi zejść do poziomu interesu obywateli" ${ }^{93}$, nie może zaś to być ,polityka wyalienowanych elit politycznych, jaką prowadziła poprzednia ekipa" ${ }^{44}$.

Krytyka elity III RP na forum parlamentu dotyczyła nie tylko okresu, kiedy była ona przy władzy, ale również jej aktualnych działań. Otóż nie może się ona pogodzić z utratą władzy i krytykuje wszelkie działania rządu. Dotyczy to np. przepisów ograniczających handel w niedzielę. Zwrócono uwagę, iż „Najbardziej krytykują tę ustawę [...] ci, którzy reprezentują Polskę elit, Polskę oligarchii, Polskę klanową, Polskę kastową" ${ }^{95}$. Stara elita prezentuje pozycję „totalnej negacji”, co jest „,wielką krzywdą wyrządzoną Polsce”, a nowa władza ,podział na bogacące się elity i biedniejące społeczeństwo przerywa" ${ }^{\prime \prime}$.

Stara elita w dalszym ciągu popełnia błędy, które już wcześniej były jej udziałem. Należy do niej ,przenoszenie wewnętrznych sporów na forum europejskie" ${ }^{\prime 97}$. Co więcej, stara władza dezinformuje zagraniczne elity o tym, że demokracja w Polsce jest zagrożona ${ }^{98}$. Zadano również pytanie, „,dlaczego europejskie elity nie były zainteresowane sytuacją w Polsce, kiedy wychodziły na jaw afery dawnej władzy"99. Ponadto podkreślano hipokryzję starych elit, które za czasów swoich rządów działały przeciwko tym, których teraz bronią, np. uchwalając przepisy podatkowe niekorzystne dla twórców ${ }^{100}$.

Można w tym miejscu stwierdzić, niejako reasumując dotychczasowe rozważania, iż „stara elita” III RP dbała wyłącznie o własne interesy, a nie o dobro społeczeństwa; w dalszym ciągu, mimo że straciła władzę, wykazywała się hipokryzją, prowadziła fatalną politykę zagraniczną, nie dbała o polską rację stanu, natomiast obecnie zajmuje się donoszeniem na nowe władze zagranicznym elitom oraz posługuje się kłamstwami (,kłamstwo wołyńskie”).

${ }_{92}$ Wystąpienie posła Roberta Winnickiego, [w:] Spraw. sten. z 23. pos. Sejmu RP $w$ dniu 20 lipca 2016 r. (drugi dzień obrad), s. 234.

93 Wystąpienie posła Ireneusza Zyski, [w:] Spraw. sten. z 10. pos. Sejmu RP..., s. 117.

94 Ibidem.

95 Wystąpienie posła Bartłomieja Stawiarskiego, [w:] Spraw. sten. z 27. pos. Sejmu RP w dniu 4 października 2016 r. (pierwszy dzień obrad), Warszawa 2016, s. 102.

96 Wystąpienie posła Kornela Morawieckiego, [w:] Spraw. sten. z 39. pos. Sejmu RP..., s. 286.

97 Wystąpienie poseł Małgorzaty Gosiewskiej, [w:] Spraw. sten. z 35. pos. Sejmu RP ..., s. 123.

98 Ibidem.

99 Wystąpienie posła Macieja Małeckiego, [w:] Spraw. sten. z 19. pos. Sejmu RP w dniu 20 maja 2016 r. (trzeci dzień obrad), Warszawa 2016, s. 348.

${ }^{100}$ Wystąpienie poseł Barbary Babuli, [w:] Spraw. sten. z 48. pos. Sejmu RP w dniu 28 września 2017 r. (drugi dzień obrad), Warszawa 2017, s. 235. 
Przy krytyce starej elity przeciwstawiano jej zupełnie odmienne działania nowej władzy. Obecne elity od poprzednich różnią się np. w sferze polityki zagranicznej: „[...] my prowadzimy realną, aktywną politykę zagraniczną, wy ograniczaliście się zazwyczaj do komunikatów na Twitterze"101. Warunkiem sukcesu jest bowiem stan „daleko idącego konsensusu w elitach politycznych, przy harmonijnej współpracy wszystkich instytucji odpowiedzialnych za politykę zagraniczną" 102 .

Nowa władza nieustannie szczyci się tym, że jej działania dotyczą zwykłych obywateli, a nie elit: „Przywróciliśmy Polakom poczucie godności i stabilizacji. Zajęliśmy się sprawami zwykłych Polaków, a nie, tak jak poprzedni rząd, sprawami elit politycznych" ${ }^{103}$. Dotyczy to m.in. reformy emerytalnej ${ }^{104}$ i reformy oświaty, które również mają służyć zwykłym ludziom, a nie elitom ${ }^{105}$.

Poza tym podkreślany był związek między dbałością o wspólny interes z suwerennością i niepodległością: ,[...] dopóki elity polskie, ludzie stanowiący prawo, będą przedkładać swój interes nad interesem całości, Polska nie będzie niepodległa i suwerenna" ${ }^{106}$.

\section{KRYTYKA ELIT SĘDZIOWSKICH}

Wśród różnych rodzajów elit poddawanych krytyce, o których była mowa w wystąpieniach sejmowych, na szczególne omówienie zasługują elity sędziowskie, przede wszystkim w związku z reformą wymiaru sprawiedliwości ${ }^{107}$. Wyraźnie daje się zauważyć, że krytyka elit sędziowskich wywodzi się głównie od przedstawicieli obozu rządzącego, a opozycja bierze je w obronę. Wielokrotnie podnoszono, iż to właśnie elity nie chcą reform w obszarze polskiego sądownictwa, mimo że jest ono powszechnie krytykowane przez obywateli. Rzecznik Praw Obywatelskich próbował uświadamiać fakt, iż reforma wymiaru sprawiedliwości

${ }^{101}$ Wystąpienie poseł Małgorzaty Gosiewskiej, [w:] Spraw. sten. z 35. pos. Sejmu RP..., s. 123.

102 Ibidem.

${ }^{103}$ Wystąpienie Prezes Rady Ministrów Beaty Szydło, [w:] Spraw. sten. z 30. pos. Sejmu RP $w$ dniu 16 listopada 2016 r. (drugi dzień obrad), Warszawa 2016, s. 221.

104 Wystąpienie posła Mieczysława Kasprzaka, [w:] Spraw. sten. z 60. pos. Sejmu RP w dniu 22 marca 2018 r. (trzeci dzień obrad), Warszawa 2018, s. 305.

105 Wystąpienie Prezes Rady Ministrów Beaty Szydło, [w:] Spraw. sten. z 29. pos. Sejmu RP $w$ dniu 3 listopada $2016 r$. (pierwszy dzień obrad), s. 106.

106 Wystąpienie posła Kornela Morawieckiego, [w:] Spraw. sten. z 19. pos. Sejmu RP..., s. 334-335.

${ }^{107}$ Należy zaznaczyć, iż krytyce mającej uzasadnić konieczność zmian w regulacjach prawnych poddawano nie tylko sędziów, ale również przedstawicieli innych zawodów prawniczych, w szczególności adwokatów i radców prawnych. Zob. Wystąpienie Podsekretarza Stanu w Ministerstwie Sprawiedliwości Marcina Warchoła, [w:] Spraw. sten. z 36. pos. Sejmu RP w dniu 24 lutego 2017 r. (drugi dzień obrad), s. 139. 
będzie mieć konsekwencje dla obywateli i nie jest to problem odnoszący się wyłącznie do aktualnie rządzącej elity ${ }^{108}$.

Elity sędziowskie zostały oskarżone m.in. o oderwanie od rzeczywistości ${ }^{109}$ oraz skłonności do korupcji. W ujęciu parlamentarzystów właśnie z tych powodów sędziowie sprzeciwiali się ujawnieniu swoich oświadczeń majątkowych ${ }^{110}$.

Należy dodać, że elity sędziowskie były brane w obronę przez przedstawicieli opozycji parlamentarnej. Próbując odpowiedzieć na pytanie, dlaczego stały się one obiektem ataku rządzących, wskazywano, iż są autorytetami, które PiS stara się ,podkopywać”, poza tym jest „to jedyna elita, która dzisiaj może państwu zagrozić" ${ }^{111}$.

W debacie nad kształtem Trybunału Konstytucyjnego, który był oskarżany o to, że „stoi na straży lobby i osób, które nie mają z Polakami nic wspólnego" ${ }^{112}$, podawano przykłady świadczące o tym, iż w wielu sprawach trudno temu organowi zarzucić, by „bronił elit”, np. gdy stanął w obronie emerytów z najniższymi świadczeniami, zniósł zakaz uboju rytualnego, zajął się ochroną dłużników przed bankowym tytułem wykonawczym, opowiedział się po stronie osób karanych za wycinkę drzew na swoich posesjach czy orzekał w sprawie działkowców ${ }^{113}$.

Wskazywano również na błędne przesłanki, jakimi uzasadniano zmiany w ustawach regulujących polski wymiar sprawiedliwości, kwestionując twierdzenie, iż o wyborze członków Krajowej Rady Sądownictwa decydowały w praktyce elity sędziowskie, podczas gdy zgodnie z obowiązującymi przepisami były to wszystkie środowiska sędziowskie ${ }^{114}$.

\section{WYMIANA ELIT}

W wystąpieniach na forum Sejmu dostrzegano proces wymiany (cyrkulacji) elit. W literaturze przedmiotu został on opisany przez Pareto jako przechodzenie jednostek z klasy niższej do wyższej oraz od klasy wyższej do niższej, a więc jako swego rodzaju falowanie społeczeństwa. Krążenie „wznosi elity wywodzące się z niższych warstw na szczyt i [...] powoduje upadek i zanik elit będących u wła-

${ }^{108}$ Wystąpienie Rzecznika Praw Obywatelskich Adama Bodnara, [w:] Spraw. sten. z 46. pos. Sejmu RP w dniu 20 lipca 2017 r. (trzeci dzień obrad), Warszawa 2017, s. 379-380.

109 Wystąpienie Sekretarza Stanu w Ministerstwie Sprawiedliwości Patryka Jakiego, [w:] Spraw. sten. z 36. pos. Sejmu RP w dniu 24 lutego 2017 r. (trzeci dzień obrad), Warszawa 2017, s. 276.

${ }^{110}$ Ibidem, s. 279.

${ }^{111}$ Wystąpienie poseł Kingi Gajewskiej-Płochockiej, [w:] Spraw. sten. z 45. pos. Sejmu RP..., s. 329 .

${ }^{112}$ Wystąpienie posła Krzysztofa Paszyka, [w:] Spraw. sten. z 6. pos. Sejmu RP..., s. 94.

113 Ibidem.

114 Wystąpienie posła Michała Stasińskiego, [w:] Spraw. sten. z 43. pos. Sejmu RP w dniu 7 czerwca 2017 r. (pierwszy dzień obrad), Warszawa 2017, s. 26. 
dzy"115. Jedna elita głodna władzy zastępuje drugą elitę, która zatraciła zdolności adaptacyjne do zmieniającej się rzeczywistości ${ }^{116}$.

Proces wymiany elit dostrzegli jednak przede wszystkim przedstawiciele opozycji, podkreślając, iż nowa władza dokonuje zmian we wszystkich dziedzinach życia, co dotyczy również elit: „Państwo po prostu zmieniacie wszystko, zmieniacie ustrój państwa, zmieniacie instytucje, zmieniacie elity [...]"117. Zmianę elit, określoną jako „proceder”, opozycja oceniła jako celowe działanie partii rządzącej. Dotyczyło ono m.in. kultury: , ,...] ten proceder wymiany elit, wymiany ludzi, wymiany działaczy, wymiany dyrektorów, wymiany tych wszystkich, którzy mają coś ważnego do zrobienia w Polsce, jest zamierzoną działalnością państwa PiS" ${ }^{118}$. Można znaleźć i takie wypowiedzi, które operują mocniejszymi określeniami dotyczącymi wymiany elit - otóż działania partii rządzącej zmierzają do tego, że zostaną one „wycięte w pień" 119 . Wymianę elit dostrzegano też w odniesieniu do elit sędziowskich: „Chcecie się pozbyć elit i oczywiście wprowadzić swoje" 120 . Jednocześnie były wskazywane konkretne osoby, które miałyby stanowić te nowe elity; co istotne, zaliczono do nich jednego z sędziów, który skazał w przeszłości byłego Prezydenta RP ${ }^{121}$.

\section{PODSUMOWANIE}

Reasumując rozważania, należy odpowiedzieć na pytanie, jaki wizerunek elit politycznych wyłania się z wypowiedzi wygłoszonych w polskim Sejmie VIII kadencji? Z pewnością obraz ten jest zdecydowanie krytyczny, gdyż pozytywnie oceniano jedynie elity historyczne (od czasów Konstytucji 3 Maja po postawę elit w czasie II wojny światowej), z wyjątkiem „tak zwanej” elity komunistycznej. Wiele zarzutów przedstawiciele aktualnej elity rządzącej postawili elitom Unii Europejskiej (tzw. elitom brukselskim) oraz elitom III Rzeczypospolitej Polskiej.

115 V. Pareto, op. cit., s. 54.

${ }^{116}$ J. Żakowski, op. cit., s. 17. Autor uważa, że w Polsce mamy do czynienia nie z cyrkulacją elit, lecz z ich zmianą, polegającą na tym, że zupełnie inne osoby mają brać udział w tym procesie.

117 Wystąpienie posła Jerzego Meysztowicza, [w:] Spraw. sten. z 53. pos. Sejmu RP w dniu 6 grudnia 2017 r. (pierwszy dzień obrad), Warszawa 2017, s. 124.

118 Wystąpienie posła Krzysztofa Mieszkowskiego, [w:] Spraw. sten. z 47. pos. Sejmu RP $w$ dniu 15 września 2017 r. (czwarty dzień obrad), Warszawa 2017, s. 358. Przywoływano przy tym przykład Węgier za rządów Viktora Orbána, gdzie pogorszyła się sytuacja ludzi kultury w tym kraju po wymianie elit w kulturze. Zob. Wystąpienie poseł Joanny Scheuring-Wielgus, [w:] Spraw. sten. z 58. pos. Sejmu RP w dniu 6 lutego 2018 r. (pierwszy dzień obrad), Warszawa 2018, s. 79.

119 Wystąpienie posła Grzegorza Furgo, [w:] Spraw. sten. z 2. pos. Sejmu RP w dniu 25 listopada 2015 r. (pierwszy dzień obrad), Warszawa 2015, s. 73.

${ }^{120}$ Wystąpienie poseł Kingi Gajewskiej-Płochockiej, [w:] Spraw. Sten. z 45. pos. Sejmu RP..., s. 329.

${ }^{121}$ Ibidem. 
Elita rządząca po 2015 r., aczkolwiek niezbyt chętnie, siebie uznaje za przedstawicieli elity politycznej, ale wyjątkowo mocno przy tym podkreśla, iż nie jest rządem elit - nie działa bowiem w interesie elit (w tym w swoim interesie), lecz dla dobra zwykłych obywateli. Dotychczasowa elita polityczna powinna zostać zastąpiona elitą narodową - zmiana ta jednak nie ogranicza się do kwestii pojęciowej, ponieważ mają to być ludzie rozpoznający potrzeby narodu. Jest to reakcja na politykę prowadzoną przez rządy III RP. Ze strony przedstawicieli elity opozycyjnej odnotowano niewiele wypowiedzi dających odpór krytycznej ocenie elit politycznych, które rządziły po 1989 r. Wyjątkiem są wypowiedzi osób biorących w obronę elity sędziowskie traktowane jako autorytety, które jako jedyne mogą stanąć na drodze działaniom aktualnej władzy. Dostrzegany jest też proces wymiany elit we wszystkich dziedzinach życia społecznego.

\section{BIBLIOGRAFIA}

Bauman Z., Elita, [w:] Wielka Encyklopedia Powszechna PWN, t. 3, Warszawa 1964.

Dubel L., Niemczyk M., O „wieczności” koncepcji elit władzy. Historia doktryn polityczno-prawnych $w$ retrospekcji teorii elit, [w:] Czas a trwanie idei politycznych i prawnych, red. K. Chojnicka, A. Citkowska-Kimla, W. Kozub-Ciembroniewicz, Warszawa 2008.

Dutkiewicz G., O pojęciu i istocie zjawiska elit, „Colloquium Wydziału Nauk Humanistycznych i Społecznych" 2012, nr 3.

Elity $w$ Polsce, w Rosji i na Wegrzech. Wymiana czy reprodukcja?, red. I. Szelenyi, D. Treiman, E. Wnuk-Lipiński, Warszawa 1995.

Grell J., Wytanianie elity władzy w Polsce Ludowej a kultura polityczna, Poznań 1989.

Janicki M., Elita znika, ,Polityka”, 4.07.2017, www.polityka.pl/tygodnikpolityka/kraj/1710972,1,kto-w-polsce-nalezy-do-elity.read [dostęp: 26.05.2018].

Keller S., Elite, [w:] International Encyclopedia of the Social Sciences, ed. D.L. Sills, Vol. 5, New York 1968.

Nocoń J., Elity polityczne. Studium interpretacji funkcjonalnej, Torun 2004.

Pareto V., Uczucia i działania. Fragmenty socjologiczne, wyb., wstęp i red. A. Kojder, Warszawa 1994.

Poczatki parlamentarnej elity. Posłowie kontraktowego Sejmu, red. J. Wasilewski, W. Wesołowski, Warszawa 1992.

Potulski J., Socjologia polityki, Gdańsk 2008.

Raciborski J., Wprowadzenie. Elity rzadowe jako przedmiot badań, [w:] Elity rzadowe III RP 19972004. Portret socjologiczny, red. J. Raciborski, Warszawa 2006.

Społeczne oceny uczciwości i rzetelności zawodowej, „CBOS. Komunikat z Badań” 2016, nr 34, www.cbos.pl/SPISKOM.POL/2016/K_034_16.PDF [dostęp: 26.05.2018].

Spraw. sten. z 2. pos. Sejmu RP w dniu 25 listopada 2015 r. (pierwszy dzień obrad), Warszawa 2015.

Spraw. sten. z 4. pos. Sejmu RP w dniu 10 grudnia 2015 r. (drugi dzień obrad), Warszawa 2015.

Spraw. sten. z 6. pos. Sejmu RP w dniu 22 grudnia 2015 r. (drugi dzień obrad), Warszawa 2015.

Spraw. sten. z 8. pos. Sejmu RP w dniu 13 stycznia 2016 r. (pierwszy dzień obrad), Warszawa 2016.

Spraw. sten. z 9. pos. Sejmu RP w dniu 28 stycznia 2016 r. (drugi dzień obrad), Warszawa 2016.

Spraw. sten. z 10. pos. Sejmu RP w dniu 29 stycznia 2016 r. (drugi dzień obrad), Warszawa 2016.

Spraw. sten. z 11. pos. Sejmu RP w dniu 10 lutego 2016 r. (drugi dzień obrad), Warszawa 2016.

Spraw. sten. z 14. pos. Sejmu RP w dniu 18 marca 2016 r. (trzeci dzień obrad), Warszawa 2016.

Spraw. sten. z 17. pos. Sejmu RP w dniu 29 kwietnia 2016 r. (trzeci dzień obrad), Warszawa 2016. 
Spraw. sten. z 18. pos. Sejmu RP w dniu 11 maja 2016 r. (pierwszy dzień obrad), Warszawa 2016. Spraw. sten. z 19. pos. Sejmu RP w dniu 20 maja 2016 r. (trzeci dzień obrad), Warszawa 2016. Spraw. sten. z 20. pos. Sejmu RP w dniu 9 czerwca 2016 r. (drugi dzień obrad), Warszawa 2016. Spraw. sten. z 23. pos. Sejmu RP w dniu 20 lipca 2016 r. (pierwszy dzień obrad), Warszawa 2016. Spraw. sten. z 23. pos. Sejmu RP w dniu 20 lipca 2016 r. (drugi dzień obrad), Warszawa 2016. Spraw. sten. z 23. pos. Sejmu RP w dniu 21 lipca 2016 r. (trzeci dzień obrad), Warszawa 2016. Spraw. sten. z 25. pos. Sejmu RP w dniu 14 grudnia 2016 r. (drugi dzień obrad), Warszawa 2016. Spraw. sten. z 27. pos. Sejmu RP w dniu 4 października 2016 r. (pierwszy dzień obrad), Warszawa 2016.

Spraw. sten. z 28. pos. Sejmu RP w dniu 19 października 2016 r. (pierwszy dzień obrad), Warszawa 2016.

Spraw. sten. z 29. pos. Sejmu RP w dniu 3 listopada 2016 r. (pierwszy dzień obrad), Warszawa 2016. Spraw. sten. z 29. pos. Sejmu RP w dniu 4 listopada 2016 r. (drugi dzień obrad), Warszawa 2016. Spraw. sten. z 30. pos. Sejmu RP w dniu 16 listopada 2016 r. (drugi dzień obrad), Warszawa 2016. Spraw. sten. z 31. pos. Sejmu RP w dniu 2 grudnia 2016 r. (czwarty dzień obrad), Warszawa 2016. Spraw. sten. z 35. pos. Sejmu RP w dniu 9 lutego 2017 r. (drugi dzień obrad), Warszawa 2017. Spraw. sten. z 36. pos. Sеjmu RP w dniu 23 lutego 2017 r. (drugi dzień obrad), Warszawa 2017. Spraw. sten. z 36. pos. Sejmu RP w dniu 24 lutego 2017 r. (trzeci dzień obrad), Warszawa 2017. Spraw. sten. z 37. pos. Sejmu RP w dniu 8 marca 2017 r. (pierwszy dzień obrad), Warszawa 2017. Spraw. sten. z 38. pos. Sejmu RP w dniu 23 marca 2017 r. (drugi dzień obrad), Warszawa 2017. Spraw. sten. z 39. pos. Sejmu RP w dniu 7 kwietnia 2017 r. (trzeci dzień obrad), Warszawa 2017. Spraw. sten. z 42. pos. Sejmu RP w dniu 24 maja 2017 r. (pierwszy dzień obrad), Warszawa 2017. Spraw. sten. z 43. pos. Sejmu RP w dniu 7 czerwca 2017 r. (pierwszy dzień obrad), Warszawa 2017. Spraw. sten. z 43. pos. Sejmu RP w dniu 8 czerwca 2017 r. (drugi dzień obrad), Warszawa 2017. Spraw. sten. z 44. pos. Sejmu RP w dniu 22 czerwca 2017 r. (trzeci dzień obrad), Warszawa 2017. Spraw. sten. z 45. pos. Sejmu RP w dniu 5 lipca 2017 r. (pierwszy dzień obrad), Warszawa 2017. Spraw. sten. z 46. pos. Sejmu RP w dniu 19 lipca 2017 r. (drugi dzień obrad), Warszawa 2017. Spraw. sten. z 46. pos. Sejmu RP w dniu 20 lipca 2017 r. (trzeci dzień obrad), Warszawa 2017. Spraw. sten. z 47. pos. Sejmu RP w dniu 15 września 2017 r. (czwarty dzień obrad), Warszawa 2017. Spraw. sten. z 48. pos. Sejmu RP w dniu 28 września 2017 r. (drugi dzień obrad), Warszawa 2017. Spraw. sten. z 49. pos. Sejmu RP w dniu 10 października 2017 r. (pierwszy dzień obrad), Warszawa 2017.

Spraw. sten. z 51. pos. Sejmu RP w dniu 9 listopada 2017 r. (drugi dzień obrad), Warszawa 2017. Spraw. sten. z 53. pos. Sejmu RP w dniu 6 grudnia 2017 r. (pierwszy dzień obrad), Warszawa 2017. Spraw. sten. z 53. pos. Sejmu RP w dniu 7 grudnia 2017 r. (drugi dzień obrad), Warszawa 2017. Spraw. sten. z 54. pos. Sejmu RP w dniu 12 grudnia 2017 r. (pierwszy dzień obrad), Warszawa 2017. Spraw. sten. z 57. pos. Sejmu RP w dniu 19 lipca 2017 r. (drugi dzień obrad), Warszawa 2017. Spraw. sten. z 58. pos. Sejmu RP w dniu 6 lutego 2018 r. (pierwszy dzień obrad), Warszawa 2018. Spraw. sten. z 59. pos. Sejmu RP w dniu 6 marca 2018 r. (czwarty dzień obrad), Warszawa 2018. Spraw. sten. z 60. pos. Sejmu RP w dniu 22 marca 2018 r. (trzeci dzień obrad), Warszawa 2018. Spraw. sten. z 61. pos. Sejmu RP w dniu 13 kwietnia 2018 r. (trzeci dzień obrad), Warszawa 2018. Spraw. sten. z pos. Zgromadzenia Narodowego w dniu 5 grudnia 2017 r., Warszawa 2017.

Stefaniuk M., Teoria elit Vilfreda Pareta, Lublin 2001.

Sztumski J., Elity - ich miejsce i rola w spoleczeństwie, Katowice 1997.

Wasilewski J., Elita, [w:] Encyklopedia socjologii, red. Z. Bokszański, A. Kojder, t. 1, Warszawa 1998

Wesołowski W., Wprowadzenie, [w:] Polityka i Sejm. Formowanie się elity politycznej, red. W. Wesołowski, B. Post, Warszawa 1998.

Żakowski J., Kwit na elity, „Polityka” 2016, nr 35.

Żyromski M., Socjologiczna teoria elity, „Ruch Prawniczy, Ekonomiczny i Socjologiczny” 1984, nr 3. 


\section{SUMMARY}

The problems investigated in the present study concern the way of how political elites are perceived in the lower chamber of the Polish Parliament, the empirical material (the subject of research) being the speeches delivered in the $8^{\text {th }}$ term Sejm of the Republic of Poland. The image of political elites is definitely critical because only the historical elites were positively assessed (from the Constitution of the $3^{\text {rd }}$ of May to the attitude of the elites during the Second World War), except for the "so-called" communist elites. Many accusations are leveled by representatives of the current ruling elite against the European Union elites (the so-called Brussels elites) and the elites of the Third Republic of Poland. The ruling elite after 2015, recognizing themselves (although reluctantly) as a political elite, very strongly emphasise that they are not the government of the elites and do not act in the interest of the latter but for the sake of ordinary citizens. The previous political elite should be replaced by the national elite. It is not merely a conceptual change but this emphasises that power should be exercised by people who correctly identify the needs of the nation. It is a reaction against the policies conducted by the governments of the Third Republic of Poland when, according to those now in power, the interest of the whole of society was not properly looked after, but only that of the elites. There are few statements by representatives of the opposition that would counter the critical assessment of the political elites which governed after 1989. The exception is the statements defending the judicial elites as authorities who are the only ones capable of opposing the actions of the current government. The process of replacement of elites is noticeable in all the spheres of social life.

Keywords: elite; power elite; political elite; ruling elite; national elite; parliamentary elite; replacement of elites

\section{STRESZCZENIE}

Problematyka podjęta w niniejszym opracowaniu dotyczy sposobu, w jaki są postrzegane elity polityczne w niższej izbie polskiego parlamentu, przy czym materiał empiryczny (przedmiot badań) stanowią wystąpienia na forum Sejmu Rzeczypospolitej Polskiej VIII kadencji. Obraz elit politycznych jest zdecydowanie krytyczny, gdyż pozytywnie oceniano jedynie elity historyczne (od czasów Konstytucji 3 Maja po postawę elit w czasie II wojny światowej), z wyjątkiem „tak zwanej” elity komunistycznej. Wiele zarzutów przedstawiciele aktualnej elity rządzącej podnoszą w stosunku do elit Unii Europejskiej (tzw. elit brukselskich) oraz elit III Rzeczypospolitej Polskiej. Elita rządząca po 2015 r., uznając siebie (choć niezbyt chętnie) za elitę polityczną, wyjątkowo mocno podkreśla, iż nie jest rządem elit i nie działa w ich interesie, lecz dla dobra zwykłych obywateli. Dotychczasowa elita polityczna powinna zostać zastąpiona elitą narodową. Nie jest to jedynie zmiana pojęciowa, lecz podkreślenie, iż władzę powinni sprawować ludzie, którzy właściwie rozpoznają potrzeby narodu. Jest to reakcja na politykę prowadzoną przez rządy III Rzeczypospolitej Polskiej, kiedy - zdaniem obecnie sprawujących władzę - nie dbano o interesy ogółu społeczeństwa, a wyłącznie elit. Ze strony przedstawicieli elity opozycyjnej niewiele jest wypowiedzi dających odpór krytycznej ocenie elit politycznych, które rządziły po 1989 r. Wyjątkiem są głosy biorące w obronę elity sędziowskie jako autorytety, które jako jedyne mogą przeciwstawić się działaniom aktualnej władzy. Dostrzegany jest proces wymiany elit we wszystkich dziedzinach życia społecznego.

Słowa kluczowe: elita; elita władzy; elita polityczna; elita rządząca; elita narodowa; elita parlamentarna; wymiana elit 